\title{
EFFECT OF LEARNED RESOURCEFULNESS ON LEARNING-CENTERED LEADERSHIP: A FIELD RESEARCH
}

\author{
DOI: 10.17261/Pressacademia.2018.864 \\ PAP- V.7-2018(17)-p.109-115
}

Ismail Bakan'1, Inci Fatma Dogan², Mehtap Kocdemir ${ }^{3}$, Makbule Oguz ${ }^{4}$

${ }^{1}$ Kahramanmars Sutcu Imam University, Kahramanmaras, Turkey. ibakan63@hotmail.com, ORCID: 0000-0001-8644-8778

${ }^{2}$ Kahramanmars Sutcu Imam University, Kahramanmaras, Turkey. ikurtulgan@gmail.com, ORCID: 0000-0002-9749-2878

${ }^{3}$ Kahramanmars Sutcu Imam University, Kahramanmaras, Turkey. mehtap.kocdemir.63@gmail.com, ORCID: 0000-0002-2220-8000 ${ }^{4}$ Kahramanmars Sutcu Imam University, Kahramanmaras, Turkey. makbule-oguzz@hotmail.com, ORCID: 0000-0002-4612-7387

To cite this document

Bakan, I., Dogan, I. F., Kocdemir, M., Oguz, M. (2018). Effect of learned resourcefulness on learning-centered leadership: a field research. PressAcademia Procedia (PAP), V.7, p.109-115.

Permemant link to this document: $h$ ttp://doi.org/10.17261/Pressacademia.2018.864

Copyright: Published by PressAcademia and limited licenced re-use rights only.

\section{ABSTRACT}

Purpose- Today, as lifelong learning becomes increasingly important, there is a growing need for learning-centered leaders who benefit from the environment, who are responsible, who make informed decisions, motivate learning, and support learning. Learning-centered leaders develop a shared vision for learning and create a supportive environment for learning development. It is believed that those who possess all these qualities should have the strategies of resolving problems in a high and superior manner. The literature on power has received considerable attention recently. The purpose of this study is to examine the effect of learned strength on learning-centered leadership.

Methodology- The research data were obtained by applying the questionnaire technique to the students studying at a state university. Findings- The data were entered into the SPSS program and subjected to frequency analysis, correlation analysis and regression analysis. Conclusion- Analysis showed that there were significant relationships between the variables and that learning power had a positive effect on learning-centered leadership.

Keywords: Learning-centered leadership, learned resourcefulness, leadership, learning, types of leadership.

JEL Codes: D83, M54, M53

\section{ÖĞRENiLMiş GÜÇLÜLÜĞÜN ÖĞRENME MERKEZLi LideRLiK ÜZERINE ETKISi: Bír ALAN ARAŞTIRMASI}

\section{ÖZET}

Amaç- Hayat boyu öğrenmenin gün geçtikçe önem kazandığı günümüzde, çevresine fayda sağlayan, sorumluluk sahibi olan, bilgiye dayalı karar veren, öğrenimi motive eden, öğrenmeyi destekleyen öğrenme merkezli liderlere olan ihtiyaç da artmaktadır. Öğrenme merkezli liderler, öğrenme için ortak bir vizyon geliştirir ve öğrenim gelişimi için destekleyici bir ortam yaratır. Tüm bu özelliklere sahip olan kişilerin zorluklarla başa çıkma azimlerinin yüksek ve üstün bir şekilde sorunları çözme stratejilerine sahip olması gerektiği düşünülmektedir. Literatürde de öğrenilmiş güçlülük konusu son zamanlarda oldukça ilgi görmektedir. Bu çalışmanın amacı öğrenilmiş güçlülüğün öğrenme merkezli liderlik üzerindeki etkisini ele almaktır.

Yöntem- Araştırma verileri, bir devlet üniversitesinde okuyan öğrencilere anket tekniği ile uygulanarak elde edilmiştir. Bulgular- Veriler SPSS programına girilerek frekans analizi, korelasyon analizi ve regresyon analizlerine tabi tutulmuştur.

Sonuç- Yapılan analizler sonucunda değişkenler arasında anlamlı ilişkiler olduğu ve öğrenilmiş güçlülüğün öğrenme merkezli liderlik üzerinde pozitif etkiye sahip olduğu sonucuna ulaşılmıştır.

Anahtar Kelimeler: Öğrenme merkezli liderlik, öğrenilmiş güçlülük, liderlik, öğrenme, liderlik türleri. JEL Kodları: D83, M54, M53 


\section{GíRiş}

Günümüzde örgütlerin çevreye uyum sağlamaları ve ayakta kalmaları, çevre şartlarına uygun ve yerinde karar almalarına, zamanında gerekli yönetsel tepkiler vermelerine bağlıdır (Şahin, 2009: ii). Gerekli yönetsel tepkilerin verilmesini kolaylaştıran unsurlardan bir tanesi de öğrenilmiş güçlülüktür. Öğrenilmiş güçlülük, kişilerin geçmişten bugüne öğrenmiş olduğu, belirledikleri amaçlarına yönelik davranışlarını engelleyen düşünce, duygu, kazanıımış davranış gibi unsurları kontrol altına almasını mümkün kılan beceriler toplamı (Rosenbaum, 1983, 1990; Akt. Güloğlu ve Aydın, 2007) olarak tanımlanmaktadır. Öğrenilmiş güçlülük, bireylerin kendi kendilerine yardım etmesini, olayları yönetebilmesini, kendi yaşamlarına hakim olabilmesini ve olumsuzlukların üstesinden gelebilmesini sağlar (Polatçı ve Boyraz, 2010: 139). Öğrenilmiş güçlülüğü yüksek olan bireyler olumsuz durumların üstesinden daha kolay gelebilmekte ve iş yaşamında daha başarılı olmaktadırlar (Yıldırım vd., 2012: 134). İ̧̧inde bulundukları olumsuz koşullara karşı öğrenilmiş güçlülüğü yüksek bireyler inatla, kararlııkla olayların olumsuz etkilerini daha kolay kontrol edebilmekte ve mevcut koşullara olumlu bir şekilde tekrar şekil vererek yaşam kalitelerini artırmaktadırlar (Tetik ve Köse, 2015: 30).

Bu çalışma kapsamında da karşılaştığı sorun ve güçlüklerle mücadelede bireylerin doğumlarından itibaren öğrenmeye başladıkları davranış repertuvarı olarak adlandırılan öğrenilmiş güçlülüğün liderlik üzerinde olumlu yönde bir etkisinin olabileceği düşünülmüş ve öğrenilmiş güçlülüğün öğrenme merkezli liderlik üzerindeki etkisi incelenmiştir.

\section{LITERATÜR TARAMASI}

Geçmişten beri liderlik kavramı insanlar üzerinde alaka ve heyecan uyandıran bir kavram haline gelmiştir. Bu açıdan liderlik, başkalarının etkinliklerine kılavuzluk etmek, koordinasyon ve düzeni sağlama ve kişileri yönlendirmek; bireylerin performanslarını değerlendirme ve onları bu konuda güdülendirmek; görevleri atamak ve kişilerin bu görevlerin getirdiği sorumlulukları gözlemek, sorunlar karşısında başarılı çözüm yolları meydana getirme ve görevlerin başarılmasında muvafık, insani ve teknik referansları sağlayabilme ve takipçilerine karşı örgütsel rehberlik rolünü ifade edebilmeyi anlatmaktır (Bernardin ve Russell, 1998; Akt. Telli ve diğerleri 2012:136). Dobbins ve Pettman'a (1997) göre, liderlik motive etme kabiliyetidir. Ortak hedeflere ulaşmak için çalışan insanlar, sıradan insanların olağanüstü performans göstermelerini sağlamak için onları motive eden kişilerde liderlik özelliği bulunmaktadır. Kısacası, liderlik, bir kişinin harekete geçmesini sağlamak, karar vermek ve genellikle başaramayacakları şeyler yapmak için kişinin becerisi, yetenekleri ve etki derecesi ile ilgilidir ( Sousa ve Rochaa, 2018:2).

Lider kolaylaştırıcı, çalışanların düşünmesini ve tartışması ve gerçekleştirmesi için önemli noktaların listelerini yaratır. Bilgi paylaşımını teşvik eden etkinlikler geliştirir, problemleri çözmeye yardımcı olur ve farklı bakış açıları ortaya çıkarmak için soruları gündeme getirir. Liderler tartışmalara rehberlik eder, ancak onu yönetmez - yapıcı eleştiriler sağlar. Organizasyonun hedeflerini anlıyor, grubu gündemde tutuyor ve ilerliyor, organizasyon faaliyetlerinde herkesi dahil ediyor ve kararların demokratik bir şekilde yapılmasını sağlıyor ( Sousa ve Rochaa, 2018:2).

Hem günlük yaşantımızda hem de eğitim yaşantımızda öğrenme hepimiz için önemli bir sözcük haline gelmiştir. Bundan dolayı liderliğin türlerinden yeni bir kavram olan öğrenme merkezli liderlik son zamanlarda gittikçe dikkat çekmektedir.

Öğrenme merkezli liderlik üzerine yapılan araştırmalar, okul liderlerinin hem öğretmenlerin hem de öğrencilerin öğrenmesini destekleyen okul kültürleri yaratma araçlarını aydınlatmaya çalışmıştır. Öğrenme merkezli liderler, okulda öğrenme için ortak bir vizyon geliştirir ve sadece öğrenci öğrenmesi için değil aynı zamanda öğretmen gelişimi için destekleyici bir ortam yaratır (Liu ve., 2016:80)

Öğrenilmiş güçlülük de bireylerin istedikleri hedeflere varabilmelerinde duygu, acı, istenmedik düşünce gibi, içsel yaşam olaylarının bozucu etkilerini kontrol altına alabilmek için başvurdukları bilişsel ve davranışsal yetenek dağarcığı olarak tanımlanmaktadır (Rosenbaum, 1983; Akt. Burçak, 2012:6). Kişilerin stresli bir durumla karşı karşıya kaldıklarında bilişsel başa çıkma stratejilerini ne düzeyde kullanabildiklerini ve kendilerini denetleme becerilerini belirten bir kavramdır (Rosenbaum, 1980, Dağ, 1991; Akt. Baydoğan ve Dağ, 2008:20).

Öğrenilmiş güçlülüğün elde edilmesinde kişinin bilişsel yönünün etkili olmasının yanı sıra eğitim, aile ve çevrenin yapısı da bu süreçte önemli bir rol oynamaktadır. Bu bakımdan öğrenilmiş güçlülük geliştirmeye açık bir vaziyettedir (Özkan ve Yıldız, 2015: 32). Öğrenilmiş güçlülük mutlak anlamda bilişsel bir durum değil, aynı zamanda eğitim yoluyla elde edilebilecek bir edinimdir (Özkan ve Yıldız, 2015: 28). Bundan dolayı öğrenilmiş güçlülüğün öğrenme merkezli liderlik üzerinde etkisi olduğu şüphesizdir.

Öğrenilmiş güçlülük durumsal koşullarla, başkalarını modelleme ile ya da eğitimle öğrenilebileceği veya artırılabileceği araştırmalarda anlatılmıştır. Rosenbaum öğrenilmiş güçlülüğün yaşam boyunca çevre ile etkileşim sonucu elde edildiğini ve güçlülük olarak tanımlanan davranışların bireyin yetiştiği çevre içerisinde öğrenildiğini ifade etmektedir. Öğrenilmiş güçlülük tanımına giren tüm yetenekler erken yaşlardan beri informal yollardan öğrenilmekte ve bireylerin öğrenme geçmişleri birbirinden farklılık gösterdiğinden dolayı, öğrenilmiş güçlülük düzeyleri de farklılık göstermektedir (Çakır, 2014:6).

Öğrenilmiş güçlülük bir davranış şekli olarak birey tarafından kazanılmıştır. Modern dünyanın getirdiği endişe, tehlike ve tehditlere daha süratli tepkiler gösterilmesi öğrenilmiş güçlülük sayesinde kazanılacaktır. Bu nedenle de öğrenilmiş güçlülük seviyesi yüksek olan kişiler yaşam ile mücadelede, stresler ile ve problemler ile etkili bir şekilde başa çıkmada ve kendini denetleme becerisinde etkin olduğu belli olacaktır. Bu bakımdan ele alındığında öğrenilmiş güçlülük bireyler açısından önemli bir role sahiptir. Bu sebepten ötürü modern yaşamda öğrenilmiş güçlülüğün nasıl meydana geldiği ve hangi kavramlarla alakalı olduğu tartışılmıştır. Öğrenilmiş güçlülük daha çok stresle başa çıkma ve olumsuz olaylara karşı bireyin kendi bilişsel repertuarını kullanarak sıkıntı ve çözümsüzlüğü en aza indirmesinde etkili olan bir kavram olarak ifade edilmiştir (Özkan ve Yıldız, 2015:36).

Tüm bu açıklamalardan da anlaşılabileceği gibi öğrenilmiş güçlülüğün öğrenme merkezli liderlik üzerinde olumlu bir şekilde etkisinin olduğu görülmektedir. 


\section{ARAŞTIRMA YÖNTEMI}

Bu araştırmanın temel amacı, öğrencilerin öğrenme merkezli liderlik düzeyleri üzerinde öğrenilmiş güçlülüğün etkili olup olmadığını ortaya çıkarmaktır. Bu amaçla, devlet üniversitesinde fakülte düzeyinde eğitim alan basit tesadüfi örnekleme yöntemi ile seçilen 398 öğrenci ile bir anket uygulaması gerçekleştirilmiştir. Anket soruları, ilgili literatürden türetilmiş olup, anket formunda açık ve kapalı uçlu soruların yanında Likert tarzı önermelere yer verilmiştir. Ankette yer alan öğrenilmiş güçlülük değişkeni araştırmada Rosenbaum'un öğrenilmiş güçlülük ölçeği ile ölçümlenmiştir. Ölçek tek boyutlu olarak ele alınmış olup toplam 36 önermeden oluşmaktadır. Önermeler Savaşır ve Şahin'in (1997) editörlüğünü yaptıkları Bilişsel-Davranışçı Terapilerde Değerlendirmede Sık Kullanılan Eserler yayınından alınmıştır. "Beni bunaltan bir iş yapmak zorunda olduğumda, bunaltımı nasıl yenebileceğimi hayal eder, düşünürüm, Başarısızlıkla birlikte gelen kötü duyguları yenmek için, sık sık kendime bunun bir felaket olmadığını ve bir şeyler yapabileceğimi telkin ederim, Yapacak çok şey olduğunda genellikle bir plan yaparım." önermeleri ölçekte yer alan ifadeler arasındadır. Öğrenme merkezli liderlik değişkenini ölçmek için Liu ve diğerleri (2016) tarafından geliştirilen, "Çevremdeki kişilerin daha iyi nasıl öğreneceklerine yönelik açık ve net fikirlere sahibim, Arkadaşlarımın nasıl daha iyi öğreneceklerine katkı sağlamak için yardımda bulunurum, Arkadaşlarıma kendi alanımızda daha bilgili olmak adına cesaret veririm. " gibi ifadelerin yer aldığı 24 soru ve 4 boyuttan oluşan ölçek kullanılmıştır. Öğrenilmişlik güçlülük ve öğrenme merkezli liderlik ölçekleri, "1: Kesinlikle katılmıyorum, 2: Katılmıyorum, 3: Kararsızım, 4: Katılıyorum ve 5: Kesinlikle katılıyorum” şeklinde beşli Likert ölçeğine göre düzenlenmiştir. Araştırmanın amaçları doğrultusunda elde edilen veriler SPSS istatistik paket programı kullanılarak analiz edilmiştir. Normallik testi için Kolmogorov-Smirnov testi uygulanmıştır. Bu test sonucunda elde edilen değer verilerin normal dağıldığını göstermiştir ve bu nedenle parametrik analiz yöntemlerinin uygulanmasına karar verilmiştir. Araştırmada geliştirilen hipotezleri test etmek amacıyla frekans, korelasyon ve regresyon analizleri kullanılmıştır.

\section{ARAŞTIRMA MODELI}

Bu çalışmada öğrencilerin öğrenilmişlik güçlülük düzeylerinin öğrenme merkezli liderlik ve öğrenme merkezli liderliğin alt boyutları üzerindeki etkisi araştırılmış ve

“H1: Öğrenilmiş güçlülüğün, öğrenme merkezli liderlik üzerinde anlamlı ve pozitif etkisi vardır.”,

“H1a: Öğrenilmiş güçlülüğün, öğrenme vizyonu geliştirme üzerinde anlamlı ve pozitif etkisi vardır.”,

"H1b: Öğrenilmiş güçlülüğün, öğrenme desteği sağlama üzerinde anlamlı ve pozitif etkisi vardır.",

“H1c: Öğrenilmiş güçlülüğün, modelleme üzerinde anlamlı ve pozitif etkisi vardır."

“H1d: Öğrenilmiş güçlülüğün, öğrenme programlarını yönetme üzerinde anlamlı ve pozitif etkisi vardır.", hipotezleri geliştirilmiştir. Geliştirilen hipotezler doğrultusunda araştırmanın modeli Şekil 1'de gösterilmektedir.

\section{Şekil 1: Araştırma Modeli}

ÖĞRENME MERKEZLi LidERLiK
Öğrenme Vizyonu Geliştirme
ÖĞRENiLMiş GürçıüLÜK
Örenme Desteği Sağlama
Modelleme
Örenme Programlarını Yönetme

Bu model kapsamında araştırmanın bağımsız değişkeni olan öğrenilmiş güçlülüğün, bağımlı değişken olan öğrenme merkezli liderlik ve öğrenme merkezli liderliğin alt boyutları üzerindeki etkisi incelenmiştir.

\section{ARAŞTIRMA BULGULARI}

Araştırma değişkenlerinin güvenirliliği, literatürde yaygın olarak kullanılan Cronbach Alfa değerleri ile ölçümlenmiştir. Buna göre Cronbach Alfa değerleri Tablo 1'de görüldüğü gibidir ve değerler öğrenme programlarını yönetme boyutu hariç Özdamar (1999)'ın orta güvenilir düzey olarak tanımladığı 0,61 ve üzerinde bulunmuştur. Öğrenme merkezli liderlik ve öğrenme programlarını yönetme değişkenlerinin değeri ise Özdamar (1999)'ın yüksek güvenilir düzey olarak tanımladığı 0,81 ve üzerinde bulunmuştur (Yaşar, 2014: 63). Öğrenme vizyonu geliştirme boyutundaki bir önerme güvenilirliği düşürmesi nedeniyle kapsam dışında tutulmuştur. 
Tablo 1: Araştırmanın Değişkenlerinin Güvenilirliği

\begin{tabular}{|l|c|c|}
\hline \multicolumn{1}{|c|}{ Değişkenler } & $\begin{array}{l}\text { Cronbach Alfa } \\
\text { Değeri }\end{array}$ & $\begin{array}{l}\text { Önerme } \\
\text { Sayıları }\end{array}$ \\
\hline Öğrenilmiş Güçlülük &, 791 & 36 \\
\hline Öğrenme Merkezli Liderlik &, 905 & 24 \\
\hline Öğrenme Vizyonu Geliştirme &, 795 & 5 \\
\hline Öğrenme Desteği Sağlama &, 762 & 8 \\
\hline Öğrenme Programlarını Yönetme &, 824 & 5 \\
\hline Modelleme &, 798 & 5 \\
\hline
\end{tabular}

Ankete katılanların cinsiyet, yaş, medeni durum, eğitim durumu gibi demografik değişkenlere göre durumları Tablo 2'de sunulmuştur.

Tablo 2: Araştırmaya Katılanların Demografik Özellikleri

\begin{tabular}{|c|c|c|c|c|c|}
\hline & Frekans & Yüzde & & Frekans & Yüzde \\
\hline $\begin{array}{l}\text { Cinsiyetiniz } \\
\text { Bay } \\
\text { Bayan } \\
\text { Toplam }\end{array}$ & $\begin{array}{l}170 \\
227 \\
398\end{array}$ & $\begin{array}{c}42,7 \\
57,0 \\
100\end{array}$ & $\begin{array}{l}\text { Ailenizin gelir düzeyi } \\
\begin{array}{l}1300 \text { ve altı } \\
1301-2000 \\
2001-3000 \\
3001-4000 \\
4001-5000 \\
5001 \text { ve üzeri } \\
\text { Toplam }\end{array}\end{array}$ & $\begin{array}{c}99 \\
125 \\
89 \\
36 \\
18 \\
27 \\
394 \\
\end{array}$ & $\begin{array}{c}24,9 \\
31,4 \\
22,4 \\
9,0 \\
4,5 \\
6,8 \\
100\end{array}$ \\
\hline $\begin{array}{l}\text { Yaşınız } \\
\qquad 18 \\
19 \\
20 \\
21 \\
22 \\
23 \\
24 \text { ve yukarısı } \\
\text { Toplam }\end{array}$ & $\begin{array}{c}29 \\
82 \\
102 \\
84 \\
44 \\
29 \\
24 \\
395\end{array}$ & $\begin{array}{c}7,3 \\
20,6 \\
25,6 \\
21,1 \\
11,1 \\
7,3 \\
6,5 \\
100\end{array}$ & $\begin{array}{l}\text { Ailedeki top. kişi sayısı } \\
2 \\
3 \\
4 \\
5 \\
6 \\
7 \\
8 \\
9 \text { ve üzeri } \\
\text { Toplam }\end{array}$ & $\begin{array}{c}10 \\
25 \\
73 \\
122 \\
68 \\
50 \\
26 \\
22 \\
396\end{array}$ & $\begin{array}{c}2,5 \\
6,3 \\
18,3 \\
30,7 \\
17,1 \\
12,6 \\
6,5 \\
5,4 \\
100 \\
\end{array}$ \\
\hline $\begin{array}{l}\text { Okuduğunuz } \\
\text { fakültenin bağlı } \\
\text { olduğu bilimdalı } \\
\text { Sosyal B. } \\
\text { Eğitim B. } \\
\text { Fen B. } \\
\text { Toplam }\end{array}$ & $\begin{array}{c}242 \\
66 \\
89 \\
398\end{array}$ & $\begin{array}{l}60,8 \\
16,6 \\
22,4 \\
100\end{array}$ & $\begin{array}{l}\text { Ailenizin gelirini temin edenler } \\
\text { çalıştığı sektör } \\
\text { Kamu S. } \\
\text { Özel S. } \\
\text { Kendi işi } \\
\text { Toplam }\end{array}$ & $\begin{array}{l}124 \\
162 \\
109 \\
397\end{array}$ & $\begin{array}{l}31,2 \\
40,7 \\
27,4 \\
100\end{array}$ \\
\hline $\begin{array}{l}\text { Sınıfınız } \\
1 \\
2 \\
3 \\
4 \\
\text { Toplam } \\
\end{array}$ & $\begin{array}{c}179 \\
91 \\
78 \\
47 \\
398 \\
\end{array}$ & $\begin{array}{l}45,0 \\
22,9 \\
19,6 \\
11,8 \\
100 \\
\end{array}$ & & & \\
\hline
\end{tabular}

Araştırma hipotezleri test edilmeden önce modelde bulunan değişkenlerin birbirleri ile ilişkilerinin istatistiksel açıdan derecesine bakılmıştır. Değişkenlere ait aritmetik ortalama ile standart sapma değerleri ve değişkenler arası korelasyon analiz sonuçları Tablo 3 ve Tablo 4'te gösterilmiştir.

Tablo 3: Araştırma Değişkenlerine Ait Ortalama ve Standart Sapma Değerleri

\begin{tabular}{lll}
\hline \multicolumn{1}{c}{ Değişkenler } & Ort & s.s. \\
\hline Öğrenilmiş Güçlülük & 3,448 &, 422 \\
Öğrenme Merkezli Liderlik & 3,878 &, 634 \\
Öğrenme Vizyonu Geliştirme & 3,814 &, 752 \\
Öğrenme Desteği Sağlama & 3,804 &, 788 \\
Modelleme & 3,908 &, 733 \\
Öğrenme Programlarını Yönetme & 3,804 &, 784 \\
\hline
\end{tabular}


Değişkenlere ait ortalama değerlere bakıldı̆̆ında en yüksek ortalamaya sahip değişkenin öğrenme merkezli liderlik değişkeninin alt boyutu olan modelleme değişkeni olduğu görülmektedir. Bu değişken anlamında katılımcıların "katılıyorum" seçeneğine yakın cevaplar verdikleri anlaşılmaktadır. En düşük ortalamaya sahip değişken ise öğrenilmiş güçlülük değişkenidir. Bu değişken bazında katılımcıların diğer değişkenlere oranla daha kararsız kaldıkları görülmektedir.

Tablo 4: Araştırma Değişkenlerinin Korelasyon Değerleri

\begin{tabular}{lcccccc}
\hline & 1 & 2 & 3 & 4 & 5 & 6 \\
1.Öğr.Güç. & 1 & & & & & \\
2.Liderlik &, $476^{* *}$ & 1 & & & & \\
3.Öğr.Viz &, $357^{* *}$ &, $824^{* *}$ & 1 & & & \\
4.Öğr.Des. &, $422^{* *}$ &, $854^{* *}$ &, $602^{* *}$ & 1 & & \\
5.Model. &, $437^{* *}$ &, $804^{* *}$ &, $565^{* *}$ &, $672^{* *}$ & 1 & \\
6.Öğr.Prog. &, $400^{* *}$ &, $876^{* *}$ &, $605^{* *}$ &, $657^{* *}$ &, $570^{* *}$ & 1 \\
\hline
\end{tabular}

Yapılan korelasyon analizi sonucuna göre öğrenilmiş güçlülük ile öğrenme merkezli liderlik ve öğrenme merkezli liderliğin tüm alt boyutları arasında $p<.05$ düzeyinde anlamlı ve pozitif yönlü ilişkiler olduğu görülmektedir. Öğrenilmiş güçlülük ile öğrenme vizyonu arasındaki ilişkinin $(r=, 357)$ diğer değişkenlere oranla daha düşük olduğu görülmüştür. Öğrenilmiş güçlülük ile öğrenme merkezli liderlik arasındaki ilişkinin $(r=, 476)$ ise diğer değişkenlere oranla daha yüksek olduğu bulgusuna ulaşılmıştır. Elde edilen bu sonuçlar çalışma kapsamında geliş̧irilen hipotezleri destekler yöndedir. Çalışmada öne sürülen hipotezleri test etmek amacıyla yapılan regresyon analizi sonuçları aşağıda yer alan tablolarda sunulmuştur.

Tablo 5: Öğrenilmiş Güçlülüğün Öğrenme Merkezli Liderlik Üzerindeki Etkisine Yönelik Regresyon Analizi

\begin{tabular}{llll}
\hline Değişkenler & Beta & t değeri & p değeri \\
\hline Öğrenme &, 476 & 10,752 &, 000 \\
Merkezli & $\mathbf{\Delta R 2 = , 2 2 4}$ & $\mathbf{F = 1 1 5 , 6 1 0}$ &, $\mathbf{0 0 0}$ \\
Liderlik & & \\
\hline
\end{tabular}

Çalışmada geliştirilen “H1: Öğrenilmiş güçülüğün, öğrenme merkezli liderlik üzerinde anlamlı ve pozitif etkisi vardır.”, hipotezini test etmek amacıyla yapılan regresyon analizi sonuçlarına göre; öğrenilmiş güçlülük bağımsız değişkeninin öğrenme merkezli liderliği $(\beta=, 476 ; \% 22,4)$ p<0,05 düzeyinde anlamlı, pozitif yönde etkilediği anlaşılmaktadır. Bu verilerden hareketle $\mathrm{H} 1$ hipotezi kabul edilmiştir.

Tablo 6: Öğrenilmiş Güçlülüğün Öğrenme Vizyonu Geliştirme Üzerindeki Etkisine Yönelik Regresyon Analizi

\begin{tabular}{llll}
\hline Değişkenler & Beta & t değeri & p değeri \\
\hline Öğrenme Vizyonu & $\mathbf{3 5 7}$ & 7,593 &, 000 \\
Geliştirme & $\mathbf{\Delta R 2 = , \mathbf { 1 2 5 }}$ & $\mathbf{F = 5 7 , 6 2 1}$ & $\mathbf{0 0 0}$ \\
\hline
\end{tabular}

Çalışmada geliştirilen "H1a: Öğrenilmiş güçlülüğün, öğrenme vizyonu geliştirme üzerinde anlamlı ve pozitif etkisi vardır.", hipotezini test etmek amacıyla yapılan regresyon analizi sonuçlarına göre; öğrenilmiş güçlülük bağımsız değişkeninin öğrenme vizyonu geliştirme değişkenini $(\beta=, 357 ; \% 12,5)$ p $<0,05$ düzeyinde anlamlı, pozitif yönde etkilediği anlaşılmaktadır. Bu verilerden hareketle H1a hipotezi kabul edilmiştir.

Tablo 7: Öğrenilmiş Güçlülüğün Öğrenme Desteği Sağlama Üzerindeki Etkisine Yönelik Regresyon Analizi

\begin{tabular}{lllll}
\hline Değişkenler & Beta & t değeri & p değeri \\
\hline Öğrenme & Desteği & $\mathbf{4 2 2}$ & 9,257 &, 000 \\
Sağlama & $\mathbf{\Delta R 2 = , \mathbf { 1 7 6 }}$ & $\mathbf{F = 8 5 , 7 0 1}$ & $\mathbf{0 0 0}$ \\
\hline
\end{tabular}

Çalışmada geliştirilen "H1b: Öğrenilmiş güçlülüğün, öğrenme desteği sağlama üzerinde anlamlı ve pozitif etkisi vardır.", hipotezini test etmek amacıyla yapılan regresyon analizi sonuçlarına göre; öğrenilmiş güçlülüğün öğrenme desteği sağlamayı $(\beta=, 422 ; \% 17,6) p<0,05$ düzeyinde anlamlı, pozitif yönde etkilediği anlaşılmaktadır. Bu verilerden hareketle $\mathrm{H} 1 \mathrm{~b}$ hipotezi kabul edilmiştir.

Tablo 8: Öğrenilmiş Güçlülüğün Modelleme Üzerindeki Etkisine Yönelik Regresyon Analizi

\begin{tabular}{llll}
\hline Değişkenler & Beta & t değeri & p değeri \\
\hline \multirow{2}{*}{ Modelleme } &, 437 & 9,648 &, 000 \\
& $\Delta R 2=, 189$ & $F=93,080$ &, 000 \\
\hline
\end{tabular}

Çalışmada geliştirilen "H1c: Öğrenilmiş güçlülüğün, modelleme üzerinde anlamlı ve pozitif etkisi vardır.", hipotezini test etmek amacıyla yapılan regresyon analizi sonuçlarına göre; öğrenilmiş güçlülüğün modellemeyi $(\beta=, 484 ; \% 23,2) p<0,05$ düzeyinde anlamlı, pozitif yönde etkilediği anlaşılmaktadır. Bu verilerden hareketle H1c hipotezi kabul edilmiştir. 
Tablo 9: Öğrenilmiş Güçlülüğün Öğrenme Programlarını Yönetme Üzerindeki Etkisine Yönelik Regresyon Analizi

\begin{tabular}{llll}
\hline Değişkenler & Beta & t değeri & p değeri \\
\hline Öğrenme &, 400 & 8,684 &, 000 \\
Programlarını Yönetme & $\mathbf{\Delta R 2 = , \mathbf { 1 5 8 }}$ & $\mathbf{F = 7 5 , 4 2 0}$ & $\mathbf{0 0 0}$ \\
\hline
\end{tabular}

Çalışmada geliştirilen "H1d: Öğrenilmiş güçlülüğün, öğrenme programlarını yönetme üzerinde anlamlı ve pozitif etkisi vardır." hipotezini test etmek amacıyla yapılan regresyon analizi sonuçlarına göre; öğrenilmiş güçlülüğün bağımsız değişkeninin öğrenme programlarını yönetme $(\beta=, 400 ; \% 15,8)$ p<0,05 düzeyinde anlamlı, pozitif yönde etkilediği anlaşılmaktadır. Bu verilerden hareketle H1d hipotezi kabul edilmiştir.

\section{SONUÇ}

Değişimin çok hızlı yaşandığı ve karmaşıklık oranının gittikçe arttığı günümüzde, her yönüyle güçlü yöneticilere, liderlere olan ihtiyaç artmaktadır. Güçlü liderlerin sahip oldukları özelliklerden bir tanesi de öğrenilmiş güçlülük düzeylerinin yüksek olmasıdır. Öğrenilmiş güçlülüğü yüksek bireyler karşılaştıkları olumsuzlukları etkili şekilde yöneterek minimize etmekte, çeşitli sorunları başarıyla çözüme kavuşturmaktadırlar. Sorunların karşısında, stresle başetmede güçlü ve özgüvenli bir şekilde durabilmektedirler. Rosenbaum (1983) da öğrenilmiş güçlülüğü tanımlarken "kişilerin içsel olayları düzenlemede kullandıkları davranışsal ve bilişsel becerilerin olayların kontrolünden çok, olayların birey üzerinde yaratacağı etkileri kontrol etmede kullanıldığına" dikkat çekmiştir (Tetik ve Köse, 2015: 34). Dolayısıyla bu çalışma kapsamında öğrenilmiş güçlülük öğrenme merkezli liderlik kavramı ile ilişkilendirilmiş ve öğrenilmiş güçlülüğün liderlik üzerindeki etkisi araştırılmıştır.

Araştırmanın amacına ulaşabilmesi için veriler anket tekniğiyle elde edilmiştir. Araştırmanın evrenini bir devlet üniversitesindeki fakülte öğrencileri oluşmaktadır. Bu evrenden basit tesadüfi örneklem ile seçilen 398 kişiye anket uygulanmış ve bu veriler araştırmanın hipotezlerini test etmek amacıyla analizlere tabi tutulmuştur. Araştırmanın amacına uygun olarak geliştirilen hipotezlerin test edilmesi için öncelikle değişkenler arasında anlamlı ilişkiler bulunup bulunmadığını ortaya çıkartmak amacıyla korelasyon analizi yapılmıştır. Bu analizlerde, araştırma hipotezleriyle uyumlu şekilde değişkenler arasında $p<.05$ düzeyinde anlamlı ilişkiler bulunmuştur. Çalışmanın amacı doğrultusunda yapılan regresyon analizi sonucunda da öğrenilmiş güçlülüğün öğrenme merkezli liderliği ve alt boyutlarını anlamlı, pozitif yönde etkilediği bulgusuna ulaşılmıştır. Elde edilen bu bulgular doğrultusunda öğrenilmiş güçlülüğü yüksek liderlerin öğrenme vizyonu geliştirme, öğrenme desteği sağlama noktasında kendisini izleyenleri olumlu şekilde etkilediği söylenilebilir. Örgütlerde karşılaştıkları olumsuz durumların etkilerini daha kolay kontrol edebilen, öğrenilmiş güçülüğü yüksek liderler çalışanlar için iyi bir rol modeli olarak amaca ve başarıya ulaşmada daha etkili olabilmektedirler. Günümüzde de bireylerin başarısı üzerinde en etkili unsurun eğitimden, deneyimden ve yetişmeden ziyade bireylerin güçlülük düzeyinin olduğu kabul edilmektedir (Coutu, 2004: 11). Bu bağlamda liderlerin öğrenilmiş güçlülük düzeylerini artırmak yolunda çalışmalar yapılması gerektiği ifade edilebilir.

Bu çalışma, araştırma kapsamındaki örneklemden elde edilen verilerle ve kullanılan yöntemlerle sınırlıdır. Bu kapsamda elde edilen bulguların genelleştirilebilirliğinin sağlanması mümkün olamamaktadır. Değişkenler arasındaki etkileşimin daha doğru ve net şekilde ortaya konulabilmesi bakımından çalışmanın farklı illerde ve sektörlerde de uygulanması ve örneklem büyüklüğünün genişletilmesi önerilebilir.

\section{KAYNAKÇA}

Baydoğan, M., Dağ, İ. (2008). Hemodiyaliz hastalarındaki depresiflik düzeyinin yordanmasında kontrol odağı, öğrenilmiş güçlülük ve sosyotropi-otonomi. Türk Psikiyatri Dergisi, 19(1), ss.19-28.

Burçak, A. D. (2012). İç denetim programının ergenlerin denetim odağı, öğrenilmiş güçlülük ve savunma mekanizmalarını kullanma biçimi üzerindeki etkisi. Doktora Tezi, Dokuz Eylül Üniversitesi Eğitim Bilimleri Enstitüsü Eğitim Bilimleri Dalı Rehberlik ve Psikolojik Danışma Bilim Dalı, ìzmir.

Coutu, D. L. (2004). Dayanıklılığın bileşenleri, örgütsel ve kişisel dayanıklılık. (Çev. A.Kardam). i̇stanbul: Acar Matbaacılık A.Ş. Türkiye Metal Sanayicileri Sendikası Yayını.

Çakır, A. (2014). Kamu sağlık sektöründe öğrenilmiş güçlülük ile stresle başa çıkma arasındaki ilişki. Doktora Tezi, İstanbul Ticaret Üniversitesi Sosyal Bilimler Enstitüsü, İşletme Anabilim Dalı, İstanbul.

Liu, S., Hallinger, P., Feng, D. (2016). Supporting the professional learning of teachers in China: does principal leadership make a difference?. Teaching and Teacher Education, 59 (2016) 79-91.

Özkan, M. S., Yıldız, Z. (2015). Öğrenilmiş güçlülük: kavramsal bir inceleme. Kara Harp Okulu Bilim Dergisi, ss.25-40.

Sousa, M. J., Rocha, A. (2018). Leadership styles and skills developed through game-based learning. Journal of Business Research $x x x(x x x x)$ $x x x-x x x$. Article in Press.

Telli, E., Ünsar, A. S., Oğuzhan, A. (2012). Liderlik davranış tarzlarının çalışanların örgütsel tükenmişlik ve işten ayrılma eğilimleri üzerine etkisi: konuyla ilgili bir uygulama. Electronic Journal of Vocational Colleges, ss.135-150.

Rosenbaum, M. (1983). Learned resourcefulness as a behavioral repertoire for the self-regulation of internal events: issues and speculations. M. Rosenbaum, C. M. Franks, Y. Jaffe (Der.), Perspectives on Behavior Therapy in the Eighties, New York, Springer, ss. 5473. 
Rosenbaum, M. (1990). The role of learned resourcefulness in the self-control of health behavior. M. Rosenbaum (Der.), Learned Resourcefulness: On Coping Skills, Self-Control, And Adaptive Behavior, New York, Springer, ss. 330.

Şahin, F. (2009). Yönetsel güçlülük: etkili yönetim ve liderlik bileşeni olarak kavramsallaştirilmasi ve ölçülebilmesine ilişkin bir araştirma. Niğde Üniversitesi Sosyal Bilimler Enstitüsü İ̧̧letme Anabilim Dalı Doktora Tezi, Niğde.

Güloğlu, B., Aydın, G. (2007). İlköğretim 5. sınıf öğrencilerinin öğrenilmiş güçlülük ve otomatik düşünce biçimi arasındaki ilişki. Hacettepe Üniversitesi Eğitim Fakültesi Dergisi, ss.157-168.

Polatçı, S., Boyraz, E. (2010). Öğretmenlerin öğrenilmiş güçlülüklerinin kaynak ve sonuçlarına ilişkin bir model önerisi. Atatürk Üniversitesi İktisadi ve İdari Bilimler Dergisi, 24(4): 137-154.

Yıldırım, M. H., Gülpınar, Ş., Uğuz, Ş. (2012). İş yaşamında öğrenilmiş güçlülük ile iş stresi arasındaki ilişkileri belirlemeye yönelik bir araştırma. Organizasyon Ve Yönetim Bilimleri Dergisi, ss.133-144.

Tetık, H. T., Köse, S. (2015). Örgüt çalişanlarının paternalistik liderlik algıları ve öğrenilmiş güçlülük düzeyleri arasındaki ilişkilerin incelenmesi. Uluslararası Yönetim İktisat ve İşletme Dergisi, 11(26): 29-56. 